\title{
Thought-action fusion and schizotypy in undergraduate students
}

\author{
Citation for published version (APA):
}

Muris, P. E. H. M., \& Merckelbach, H. L. G. J. (2003). Thought-action fusion and schizotypy in undergraduate students. British Journal of Clinical Psychology, 42, 211-216.

https://doi.org/10.1348/014466503321903616

Document status and date:

Published: 01/01/2003

DOI:

10.1348/014466503321903616

Document Version:

Publisher's PDF, also known as Version of record

\section{Please check the document version of this publication:}

- A submitted manuscript is the version of the article upon submission and before peer-review. There can be important differences between the submitted version and the official published version of record.

People interested in the research are advised to contact the author for the final version of the publication, or visit the DOI to the publisher's website.

- The final author version and the galley proof are versions of the publication after peer review.

- The final published version features the final layout of the paper including the volume, issue and page numbers.

Link to publication

\footnotetext{
General rights rights.

- You may freely distribute the URL identifying the publication in the public portal. please follow below link for the End User Agreement:

www.umlib.nl/taverne-license

Take down policy

If you believe that this document breaches copyright please contact us at:

repository@maastrichtuniversity.nl

providing details and we will investigate your claim.
}

Copyright and moral rights for the publications made accessible in the public portal are retained by the authors and/or other copyright owners and it is a condition of accessing publications that users recognise and abide by the legal requirements associated with these

- Users may download and print one copy of any publication from the public portal for the purpose of private study or research.

- You may not further distribute the material or use it for any profit-making activity or commercial gain

If the publication is distributed under the terms of Article $25 \mathrm{fa}$ of the Dutch Copyright Act, indicated by the "Taverne" license above, 


\title{
Thought-action fusion and schizotypy in undergraduate students
}

\author{
Peter Muris' and Harald Merckelbach ${ }^{2}$ \\ 'Department of Medical, Clinical, and Experimental Psychology, Maastricht \\ University, The Netherlands \\ ${ }^{2}$ Department of Psychology, Maastricht University, The Netherlands
}

Objective. To examine the relationship between thought-action fusion (TAF) and schizotypy.

Method. In two separate samples of undergraduate students ( $N s=77$ and 64), correlations were computed between a measure of TAF and indices of schizotypy and fantasy proneness.

Results. Positive correlations were found between TAF and various aspects of schizotypy (i.e. perceptual aberration, magical ideation, schizotypal personality characteristics, disposition to hallucinate). However, correlations between TAF and schizotypy no longer attained significance when controlling for fantasy proneness.

Conclusion. At least in the non-clinical population, the connection between TAF and schizotypy seems to be a by-product of fantasy-prone individuals' tendency to report unusual experiences.

Thought-action fusion (TAF) refers to a cognitive bias that may increase people's sense of responsibility for their intrusions and hence can be regarded as a vulnerability factor for the development of clinical obsessions (e.g. Rachman \& Shafran, 1999). There are two types of TAF biases: TAF-morality, which pertains to the belief that unacceptable thoughts are morally equivalent to overt actions, and TAF-likelihood, which refers to the belief that thinking of an unacceptable or disturbing situation will increase the probability that it will happen in the near future.

There is indeed empirical support for the presumed role of TAF in the exacerbation of intrusive thoughts as seen in obsessive-compulsive disorder (OCD). To begin with, Rassin, Merckelbach, Muris, and Spaan (1999) showed that TAF influences participants' 
appraisal of the significance of intrusions. Participants were led to believe that thinking about the word 'apple' could result in the administration of an electrical shock to another person. Results indicated that this experimentally induced TAF promoted intrusive thinking in that it resulted in a higher frequency of target thoughts (i.e. thoughts about the word 'apple'), more discomfort and more resistance. Secondly, correlational studies found that TAF is associated with symptoms of various anxiety disorders, but in particular with symptoms of OCD (Muris, Meesters, Rassin, Merckelbach, \& Campbell, 2001; Rachman, Thordarson, Shafran, \& Woody, 1995; Rassin, Diepstraten, Merckelbach, \& Muris, 2001; Shafran, Thordarson, \& Rachman, 1996). Furthermore, by means of structural equation modelling Rassin, Muris, Merckelbach, and Schmidt (2000) demonstrated that TAF can be best considered as an antecedent of OCD symptoms. Thirdly, participants with obsessional symptoms have been found to display higher levels of TAF than those without such symptoms (Shafran et al., 1996).

Schizotypy can be defined as the tendency to report schizophrenia-like symptoms. Individuals who are high on this trait are characterized by:

ideas of reference (i.e., incorrect interpretations of causal incidents and external events as having a particular and unusual meaning specifically for the person), [they] are superstitious or preoccupied with paranormal phenomena that are outside the norms of their subculture, [and] believe that they may have magical control over others, which can be implemented directly (e.g., believing that their spouse taking the dog out for a walk is the direct result of thinking it should be done an hour earlier) or indirectly through compliance with magical rituals (e.g., walking past a specific object three times to avoid a certain harmful outcome). (American Psychiatric Association, 1994; p. 64I)

Chapman, Chapman, Kwapil, Eckblad, and Zinser (1994) found evidence to suggest that schizotypy increases the risk for developing psychosis. In their study, participants with high schizotypy levels were more likely to suffer from psychosis at 10 years followup compared with control participants.

Obviously, there are similarities between schizotypy and TAF. Specifically, schizotypal features such as 'ideas of reference', 'superstition' and 'magical thinking' also seem to constitute the cognitive distortions of TAF. Interestingly, OCD patients relatively often display comorbid schizotypal personality disorder (Baer \& Jenike, 1992), and even in non-clinical samples there is a robust correlation between scores on OCD inventories and those on measures of schizotypy (Roth \& Baribeau, 2000). However, Rachman and Shafran (1999; p. 83) noted that 'TAF . . is distinct from the phenomenon in psychosis in that there is full insight that TAF is irrational, "magical", and that thoughts alone cannot produce harmful events'.

Currently, no study can be found in the literature that has directly examined the relationship between TAF and schizotypy. The present investigation was a first attempt to address this issue. In two separate samples of undergraduate students, correlations between a measure of TAF and indices of schizotypy were computed in order to test whether both constructs define a common domain. In both samples, we also included a measure of fantasy proneness as it is known that individuals who score high on this trait display a positive response bias on questionnaires with a bizarre or atypical content (such as measures of TAF and schizotypy), leading to high rates of endorsement of eccentric items (e.g. Merckelbach \& Muris, 2001; Merckelbach \& Smith, 2003). 


\section{Method}

\section{Participants}

Sample 1 consisted of 77 undergraduate students (43 women and 34 men; mean age $=21.0, S D=1.9$, range 18-27) who completed the following measures: the TAF scale (Shafran et al., 1996), the 'magical ideation' and 'perceptual aberration' scales of the Wisconsin Psychosis-Proneness Inventory (WPPI; Chapman \& Chapman, 1980), and the Creative Experiences Questionnaire (CEQ; Merckelbach, Horselenberg, \& Muris, 2001).

Sample 2 consisted of 64 undergraduates $(55$ women and 9 men; mean age $=19.5$, $S D=1.7$, range 18-24) who filled out the TAF scale, the Schizotypal Personality Scale (STA; Claridge \& Broks, 1984), the Launay-Slade Hallucination Scale (LSHS; Launay \& Slade, 1981) and the CEQ.

\section{Questionnaires}

The TAF scale contains 19 items addressing the cognitive distortions that involve TAF. Sample items are 'Having a blasphemous thought is almost as sinful to me as a blasphemous action' and 'If I think of myself falling ill, this increases the risk that I will fall ill'. All items are answered on a 5-point scale $(0=$ disagree strongly, $4=$ agree strongly). Scores are summed to obtain a total score, with higher scores reflecting stronger TAF bias.

The WPPI includes six scales that intend to measure different aspects of schizotypy, viz. magical ideation, perceptual aberration, social anhedonia, physical anhedonia, impulsive non-conformity and hypomanic personality. In the current study, only the magical ideation and the perceptual aberration scales were used, as longitudinal research has shown that scores on these scales best predict subsequent psychotic symptomatology (Chapman et al., 1994). The magical ideation scale consists of 30 items (e.g. 'Sometimes I have felt the presence of an evil spirit nearby, although I could not see anything', 'Numbers like 13 and 7 have special power') measuring beliefs of causality that, according to the conventional standards of Western culture, are considered as invalid and/or magical (e.g. superstition, thought transmission, precognition, spiritual influences). The perceptual aberration scale contains 33 items (e.g. 'I sometimes had the feeling that my body was abnormal', 'Sometimes I have to touch myself to be sure that I still exist') assessing distorted perceptions of one's own body. Both WPPI scales have a true-false response format. After reversed coding of some items, scores are summed to yield total scores, with higher scores indicating higher levels of magical ideation and perceptual aberration.

The CEQ is a 25-item measure of fantasy proneness. Respondents have to indicate 'yes' or 'no' to statements such as 'As a child, I could very easily identify with the main character of a story or movie', 'When I recall my childhood, I have very vivid and lively memories' and 'I can recall many occurrences before the age of three'. 'Yes' answers are summed to obtain a total score, with higher scores reflecting higher levels of fantasy proneness.

The STA is a questionnaire consisting of 37 dichotomous items that are closely modelled on the DSM criteria for schizotypal personality disorder. Thus, the STA primarily taps the cognitive and social-anxiety aspects of schizotypy (e.g. 'Are you sometimes sure that other people can tell what you are thinking?', 'Do you ever feel that your thoughts do not belong to you?', 'Do you sometimes feel that people are 
talking about you?') 'Yes' answers are summed to yield a total score, with higher scores indicating a higher frequency of schizophrenia-like symptoms.

The LSHS is a widely used instrument for measuring the disposition to hallucinate. It consists of 12 items that refer to hallucinatory experiences. Sample items are 'Sometimes my thoughts seem as real as actual events in my life' and 'I have been troubled by hearing voices in my head'. Respondents score each item on a 5-point scale $(0=$ certainly does not apply, $4=$ certainly applies). Scores are summed to obtain a total score, with higher scores reflecting a stronger disposition towards hallucinatory experiences.

\section{Results and discussion}

Cronbach's alphas for the TAF scale were .91 and .93 in Samples 1 and 2, respectively, and varied between .72 and .86 for the other questionnaires, indicating that the internal consistency of all scales was satisfactory. In Sample 1, the mean scores on various measures were $17.4(S D=11.1)$ for the TAF scale, $4.9(S D=4.1)$ for WPPI magical ideation, $3.5(S D=3.7)$ for WPPI perceptual aberration, and $6.4(S D=3.7)$ for CEQ fantasy proneness. In Sample 2, mean scores were $19.5(S D=12.7)$ for the TAF scale, $10.5(S D=5.7)$ for STA schizotypy, $11.8(S D=6.7)$ for LSHS hallucination predisposition, and $6.3(S D=3.8)$ for CEQ fantasy proneness. Note that these scores come close to average values as previously reported for non-clinical samples (Bentall, Claridge, \& Slade, 1989; Chapman \& Chapman, 1980; Merckelbach et al., 2001; Merckelbach, Rassin, \& Muris, 2000; Merckelbach \& Van de Ven, 2001; Rassin et al., 2000).

Pearson product-moment correlations between TAF, magical ideation, perceptual aberration and fantasy proneness (Sample 1) showed small but significant positive correlations were found between TAF on the one hand, and magical ideation and perceptual aberration on the other ( $r$ being $.27, p<.05$ and $.25, p<.05$, respectively). Thus, higher levels of TAF were accompanied by higher levels of schizotypal traits. Furthermore, TAF was significantly connected to fantasy proneness $(r=.43, p<.001)$. When the contribution of fantasy proneness was statistically removed, correlations between TAF and schizotypal traits no longer attained significance. Thus, partial $r$ s between TAF and magical ideation and perceptual aberration were .08 and .11, respectively, when the contribution of fantasy proneness was controlled for.

Correlations among TAF, schizotypy, disposition to hallucinate, and fantasy proneness (Sample 2) indicated that TAF was significantly linked to both schizotypy as indexed by STA and fantasy proneness ( $r$ s being $.30, p<.05$ and $.31, p<.05$, respectively), and marginally significantly associated with the disposition to hallucinate $(r=.23, p=.06)$. When holding fantasy proneness constant, partial correlations between TAF and schizotypy and disposition to hallucinate fell to non-significance (partial $r$ s being .12 and .05 , respectively).

The clinical literature offers several examples of studies that found some overlap between OCD and schizotypy (e.g. Sobin et al., 2000; for a review see Enright \& Beech, 1997). As TAF seems to be involved in the pathogenesis of OCD and bears resemblance to certain aspects of schizotypy (e.g. magical ideation, superstition), one might hypothesize that TAF is responsible for the covariance of OCD and schizotypy. The present data lend no support to this idea. Correlations between TAF and indices of schizotypy were significant, but small, suggesting that these constructs can be distinguished. Furthermore, these correlations disappeared when the influence of 
fantasy proneness was partialled out. Thus, it appears that the connections between TAF and schizotypy are carried by fantasy proneness. A clear preoccupation with unusual cognitions and perceptions is what TAF, schizotypy and fantasy proneness have in common (e.g. Watson, 2001). However, while TAF is outwardly directed in the sense that it has behavioural consequences (checking, neutralizing; e.g. Rassin et al., 1999), schizotypal features do not necessarily manifest themselves in overt action. This, then, might explain why the connection between TAF and schizotypy disappears, once one corrects for fantasy prone individuals' preference for unusual experiences. To sum up, then, our results support Rachman and Shafran's (1999) intuition that TAF is distinct from schizophrenia-like experiences. It should be borne in mind, however, that the present study relied on normal participants, and so the generalizability of the current findings to clinical populations remains to be established. In particular, the precise meaning of the moderate correlations between TAF and fantasy proneness requires further study (see also Rassin, Merckelbach, Muris, \& Schmidt, 2001). Perhaps fantasy-prone individuals tend to exaggerate risk probabilities, and this might fuel TAF bias.

\section{References}

American Psychiatric Association (1994). Diagnostic and statistical manual of mental disorders (4th ed.). Washington, DC: American Psychiatric Association.

Baer, L., \& Jenike, M. A. (1992). Personality disorders in obsessive-compulsive disorder. Psychiatric Clinics of North America, 15, 803-811.

Bentall, R. P., Claridge, G., \& Slade, P. D. (1989). The multidimensional nature of schizotypal traits: A factor analytic study with normal subjects. British Journal of Clinical Psychology, 28, 363-375.

Chapman, L. J., \& Chapman, J. P. (1980). Scales for rating psychotic and psychotic-like experiences as continua. Schizophrenic Bulletin, 6, 476-489.

Chapman, L. J., Chapman, J. P., Kwapil, T. R., Eckblad, M., \& Zinser, M. C. (1994). Putatively psychosis-prone subjects 10 years later. Journal of Abnormal Psychology, 103, 171-183.

Claridge, G., \& Broks, P. (1984). Schizotypy and hemisphere function: Theoretical considerations and the measurement of schizotypy. Personality and Individual Differences, 5, 633-648.

Enright, S., \& Beech, A. (1997). Schizotypy and obsessive-compulsive disorder. In G. Claridge (Ed.), Schizotypy: Implications for illness and bealth (pp. 202-223). New York: Oxford University Press.

Launay, G., \& Slade, P. D. (1981). The measurement of hallucinatory predisposition in male and female prisoners. Personality and Individual Differences, 2, 221-234.

Merckelbach, H., Horselenberg, R., \& Muris, P. (2001). The Creative Experiences Questionnaire (CEQ): A brief self-report measure of fantasy proneness. Personality and Individual Differences, 31, 987-996.

Merckelbach, H., \& Muris, P. (2001). The causal link between self-reported trauma and dissociation: A critical review. Behaviour Research and Therapy, 39, 245-254.

Merckelbach, H., Rassin, E., \& Muris, P. (2000). Dissociation, schizotypy, and fantasy proneness in undergraduate students. Journal of Nervous and Mental Disease, 188, 428-431.

Merckelbach, H., \& Smith, G. P. (2003). Diagnostic accuracy of the Structured Inventory of Malingered Symptomatology (SIMS) in detecting instructed malignering. Archives of Clinical Neuropsychology, 18(2), 145-152.

Merckelbach, H., \& Van de Ven, V. (2001). Another White Christmas: Fantasy proneness and reports of 'hallucinatory experiences' in undergraduate students. Journal of Behavior Therapy and Experimental Psychiatry, 32, 137-144. 
Muris, P., Meesters, C., Rassin, E., Merckelbach, H., \& Campbell, J. (2001). Thought-action fusion and anxiety disorders symptoms in normal adolescents. Behaviour Research and Therapy, 39, 843-852.

Rachman, S. J., \& Shafran, R. (1999). Cognitive distortions: Thought-action fusion. Clinical Psychology and Psychotherapy, 6, 80-85.

Rachman, S., Thordarson, D. S., Shafran, R., \& Woody, S. R. (1995). Perceived responsibility: Structure and significance. Behaviour Research and Therapy, 33, 779-784.

Rassin, E., Diepstraten, P., Merckelbach, H., \& Muris, P. (2001). Thought-action fusion and thought suppression in obsessive-compulsive disorder. Behaviour Research and Therapy, 39, 757-764.

Rassin, E., Merckelbach, H., Muris, P., \& Schmidt, H. (2001). The thought-action fusion scale: Further evidence for its reliability and validity. Behaviour Research and Therapy, 139, 537544.

Rassin, E., Merckelbach, H., Muris, P., \& Spaan, V. (1999). Thought-action fusion as a causal factor in the development of intrusions. Behaviour Research and Therapy, 37, 231-237.

Rassin, E., Muris, P., Merckelbach, H., \& Schmidt, H. (2000). Relationships between thoughtaction fusion, thought suppression, and obsessive-compulsive symptoms: A structural equation modeling approach. Behaviour Research and Therapy, 38, 889-898.

Roth, R. M., \& Baribeau, J. (2000). The relationship between schizotypal and obsessivecompulsive features in university students. Personality and Individual Differences, 29, 10831093.

Shafran, R., Thordarson, D. S., \& Rachman, S. (1996). Thought-action fusion in obsessivecompulsive disorder. Journal of Anxiety Disorders, 10, 379-391.

Sobin, C., Blundell, M. L., Weiller, F., Gavigan, C., Haiman, C., \& Karayiorgou, M. (2000). Evidence of schizotypy subtype in OCD. Journal of Psychiatric Research, 34, 15-24.

Watson, D. (2001). Dissociations in the night: Individual differences in sleep-related experiences and their relation to dissociation and schizotypy. Journal of Abnormal Psychology, 110, 526535.

Received 13 February 2002; revised version received 24 September 2002 